Revue Française de Civilisation Britannique United Kingdom Since the Nineteenth Century

\title{
King Coal Rules: Accepting or Refusing Coal Dependency in Victorian Britain
}

Le Règne du roi charbon: accepter ou refuser la dépendance au charbon à l'ère

Victorienne

\section{Charles-François Mathis}

\section{OpenEdition}

Journals

Electronic version

URL: http://journals.openedition.org/rfcb/2498

DOI: $10.4000 /$ rfcb.2498

ISSN: 2429-4373

Publisher

CRECIB - Centre de recherche et d'études en civilisation britannique

Electronic reference

Charles-François Mathis, « King Coal Rules: Accepting or Refusing Coal Dependency in Victorian Britain », Revue Française de Civilisation Britannique [Online], XXIII-3 | 2018, Online since 01 December 2018, connection on 19 April 2019. URL : http://journals.openedition.org/rfcb/2498; DOI : 10.4000/ rfcb.2498

This text was automatically generated on 19 April 2019

\section{cc)}

Revue française de civilisation britannique est mis à disposition selon les termes de la licence Creative Commons Attribution - Pas d'Utilisation Commerciale - Pas de Modification 4.0 International. 


\title{
King Coal Rules: Accepting or Refusing Coal Dependency in Victorian Britain
}

\author{
Le Règne du roi charbon: accepter ou refuser la dépendance au charbon à l'ère \\ Victorienne
}

Charles-François Mathis

\section{Introduction}

\begin{abstract}
When our coal mines are exhausted, the prosperity and glory of this flourishing and fortunate island are at an end. Our cities and great towns must then become ruinous heaps for want of fuel, and our mines and manufactories must fail from the same cause, and then consequently our commerce must vanish. In short, the commerce, wealth, importance, glory, and happiness of Great Britain will decay and gradually dwindle to nothing, in proportion as our coal and other mines fail; and the future inhabitants of this island must live, like its first inhabitants, by fishing and hunting. ${ }^{1}$
\end{abstract}

1 In this excerpt from his Natural History of the Mineral Kingdom (1789), John Williams expressed one of the first concerns about coal shortage and its consequences on the British future. Few countries indeed relied so exclusively on a single source of energy for all their needs. As early as 1620 , according to Paul Warde, about half of the country's energy needs were met by coal. This figure reached $77 \%$ in 1800 and $95 \%$ in $1900 .{ }^{2}$ England can thus be viewed as an extreme case of energy servitude to coal in the $19^{\text {th }}$ century. What changed from the end of the $18^{\text {th }}$ century onwards was the growing use of coal in industry and the shift from an organic economy to a fossil-based one. ${ }^{3}$ From then on, coal was not only used for domestic purposes and in a few industrial sectors (mainly the textile and iron industries), it progressively became the staple of the British economy. Concerns about coal, its supply and its effects on the daily life of the population, had, up to then, been mainly local: William Cavert has devoted a brilliant analysis on how it came to be a major issue for Londoners in the $17^{\text {th }}$ and $18^{\text {th }}$ centuries. ${ }^{4}$ Afterwards, these 
concerns were extended to a national scale and, as John Williams's excerpt testifies, they questioned the duration of Britain's supremacy.

From this moment onwards, worries about a possible shortage of coal were expressed every now and then; they reached a properly political dimension in 1829-1830 when the state of the coal trade was discussed. Fredrik Albritton Jonsson, whose work focuses on this issue up to the end of the 1860s, has shown how two rival futures for coal competed throughout the period and fed on each other for their development - one favouring the optimistic view of quasi-inexhaustible supplies, the other warning of dark times to come when coal became exhausted. ${ }^{5}$ These fears were for instance reactivated in the mid-1840s, when PM Robert Peel abolished the coal duties that he had revived a few years earlier. The passing thought of shortage was also expressed by The Times in 1849 upon the opening of the new building of the London Coal Exchange: "if not the single element of our mercantile and political superiority, coal is at least absolutely essential; and could we suppose such an event as the exhaustion of the beds, it would be the final and utter catastrophe of our greatness" .6

Early in the century, then, the British elites were fully aware of the fearful dependence of the country on its coal supplies. But this issue was never really tackled; it came and went according to the social or political agenda. The first explanation for such behaviour is of course the invisibility of the issue: coal was abundant and cheap, and no scarcity was usually felt; worries were only expressed when coal prices increased. But, and this is the second explanation, these worries were soon appeased by the experts' estimates of remaining supplies. Even though the predicted life-lengths of coalfields strongly varied from one expert to the other, ${ }^{7}$ they tended to be reassuring - and the very variations of these predictions highlighted the technical problems they faced, and therefore the likelihood of far more coal beds than expected. Finally, the mere scale of the problem how can a society deal with its utter dependence on a single energy source - made it nearly impossible to imagine any way out.

4 So, up to the 1860 s, the issue of coal shortage and dependence was at the same time perceived and marginalised. What I propose to discuss in this article is how and why this changed in the 1860s-1870s, when this issue was more discussed than ever, even though it ended up being cast aside once more. To do so, I will rely on the vast literature that appeared at the time on the topic, whether in the press, in books or in political speeches and parliamentary papers.

\section{The early 1870s: when long- and short-term fears converge}

5 At the beginning of the 1870s, the visibility of what became known as "the coal question" was increased and more difficult than ever to ignore by the population at large. This was mainly due to the convergence of two different kinds of fears: long-term and short-term ones. This distinction was made by the medieval historian Jean Delumeau to differentiate between the well-thought-out fears expressed by intellectuals and politicians, and the spontaneous and momentary panics of more common people. ${ }^{8}$ In the case of coal in the 19 th century, such a frame of analysis can be applied to distinguish the climate of anxiety created by economists, geologists or politicians, who reflected upon coal supply and its 
future scarcity since the late 1700s, and the short-term panics born out of coal shortage and high prices.

\section{1) A renewed anxiety about coal shortage}

6 The long-term anxiety about coal shortage was renewed and strengthened by the publication in 1865 , by the economist Stanley Jevons, of The Coal Question, ${ }^{9}$ in which, basing his calculations not on geological estimates only, but also on economic laws and tendencies, he gave Britain a mere 100 years left of coal supplies before decline. ${ }^{10}$ According to him, a continuous growing demand for coal would exhaust British resources more quickly than expected. ${ }^{11}$ This triggered considerable anxieties, that were echoed in the general or specialised press: The Times, The Economist, The Saturday Review, The Quarterly Review, all commented upon it; ${ }^{12}$ the Colliery Guardian proposed throughout the year 1866 articles on "National Prosperity dependent on national resources", ${ }^{13}$ on "the coal supply of Europe and America", ${ }^{14}$ on the "coal supply"15 or on "the coal panic". ${ }^{16}$

7 All the books dealing with coal mentioned Jevons's theories, whether to support or question them. To take but one example, the eminent geologist Sir Warrington Wilkinson Smyth, in his 1867 Treatise on Coal and Coal Mining, mentions that "public attention has been forcibly called (...) to the question of the duration of the coal fields" and that "the time for prudent forethought has arrived". ${ }^{17}$

8 The issue was even discussed in Parliament, where PM Gladstone and John Stuart Mill commented upon Jevons' conclusions and asked for enquiries. The same mechanism as in previous and similar circumstances was applied: a Royal Commission on coal supply was appointed in 1866 and handed its 22-volume conclusions in 1871. These were very reassuring: the main conclusion of the report was that Jevons had been mistaken in considering an increase of consumption in the future at the same rate as previous years. And even if coal consumption did increase so, there would still be more than 300 hundred years of coal supply for the country - whereas if consumption remained what it was in 1871, there would be coal for more than one and a half thousand years. ${ }^{18}$ This, as previous estimates had done, should have considerably alleviated the fears, and the coal question should have been dismissed once again and disappeared for a while. But this time, something else happened.

\section{2) When dependence is felt: the coal famine}

9 A dependence, a servitude, becomes visible in times of want; one only feels an addiction ${ }^{19}$ when the addicting product is missing: this is exactly what happened between 1871 and 1873, when coal prices started to increase dramatically. Even though there was no uniform price of coal in the country, Roy Church has calculated that average pit prices more than doubled between 1870 and $1873 .{ }^{20}$ According to a coal merchant, the price of a ton of coal in London went from 18.6 shillings in 1870 to more than 32 shillings in $1873 .{ }^{21}$ According to Roy Church, these were the highest prices ever reached by coal in the $19^{\text {th }}$ century, despite peaks in 1837, 1847 and 1854, and later in 1890 and 1900. The sufferings of the population were therefore intense, in London as well as in other towns deprived of local and more easily available coal. This was the time when the phrase "Old King Coal", popularised in 1859 in a poem by Charles Mackay in the Illustrated London News, ${ }^{22}$ was more widely used to describe a tyrannical sovereign. ${ }^{23}$ On March 1873, for instance, the 
magazine Fun published a terrifying drawing in which King Coal sat on a heap of coal sacks, watching children dying of cold and starvation. A poem accompanied the picture, warning that:

Old King Coal

Is a knowing old droll

A knowing old droll is he:

For he's paying no wages and profits they roll

In fast, at the prices that be.

Fifty-four, fifty-five, fifty-six, go the prices

And he doesn't care

For the deep despair

Of the sons of penury. ${ }^{24}$

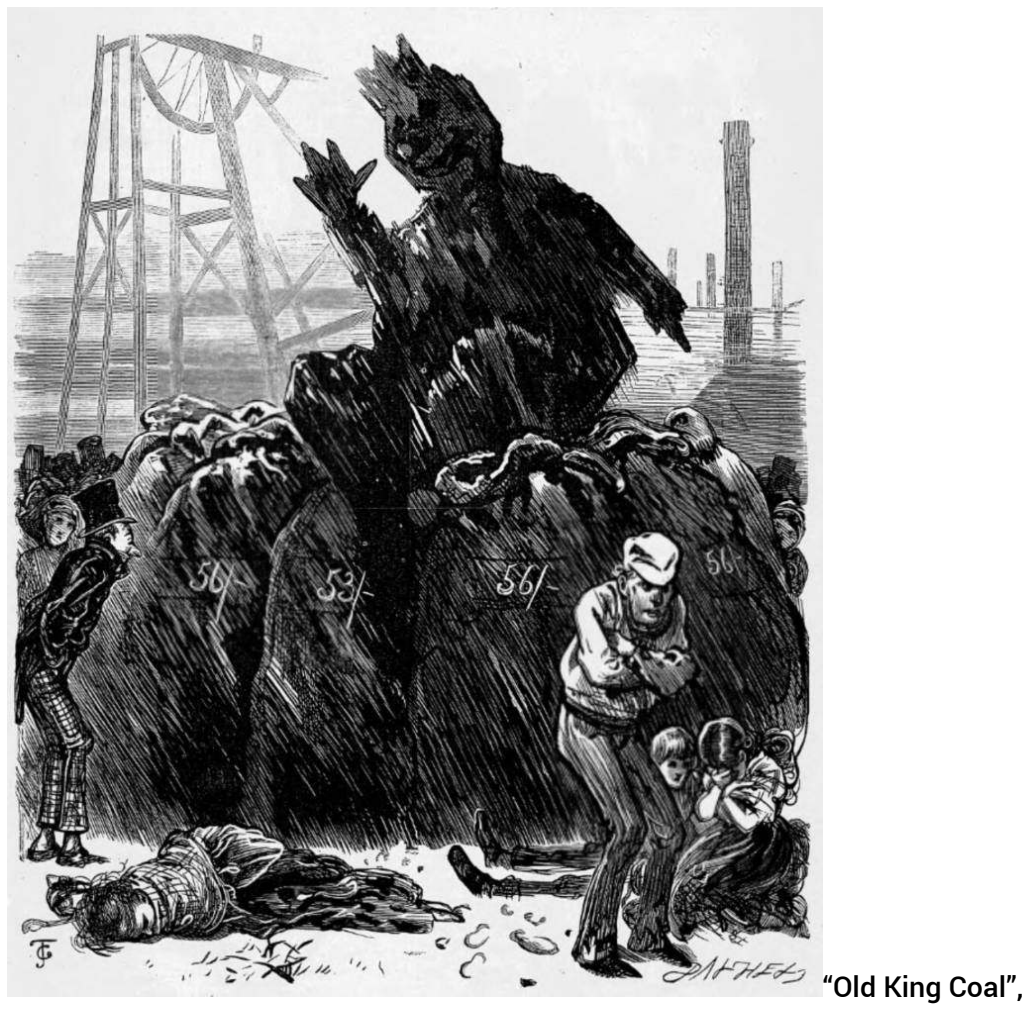

Growing discontent was perceptible in the population, leading to what was called at the time "indignation meetings". ${ }^{25}$ They took place all over the country from February 1873 onwards, when coal prices were increasing very quickly. For instance, on the $24^{\text {th }}$ of February 7 to 8000 people gathered in Nottingham to complain about the situation, ${ }^{26}$ and in London, meetings took place in Trafalgar Square or in Clerkenwell. ${ }^{27}$

11 It was not the first time, of course, that the population suffered from high coal prices: William Cavert has shown such hardships in $17^{\text {th }}$ or $18^{\text {th }}$-century London for instance. ${ }^{28}$ But in 1871-1873, the "famine" as it was called lasted longer than expected, and did not occur at a time of national crisis: there was no war or specific catastrophe to justify it. Moreover, it was the first time that it happened just when the country was wondering how long coal would last. Was it not the proof that Jevons was finally right, earlier than expected, and that Britain's doom was close? Finally, this was the time when Britain entered a period of doubts about its model, of anxiety about the future of its race and therefore of the country itself; a time also when considerable worries about urban evils were expressed. Fears of the mob and of decline combined to heighten the awareness of 
public authorities and analysts. For all these reasons, this year was certainly a turning point in the thoughts about British dependence on coal. ${ }^{29}$

\section{The temporary failure of marginalisation}

\section{1) A Committee to fight "delusions"}

12 This time, indeed, the issue took time to be cast aside. After some hesitations, ${ }^{30}$ Parliament appointed a Select Committee on Dearness and Scarcity that started working in late February 1873, and handed its report as early as July 1873 . It acted therefore rather fast, certainly in order to calm the growing agitation and the rather unpleasant suspicion that was spreading among the population of the existence of a "coal ring" uniting coalowners and merchants who were speculating on the rise in prices. In the House of Lords, the Duke of Richmond had warned that "men were suffering greatly, and might not remain quiet much longer. Government should look into it" ${ }^{31}$ The Committee explained the rise in prices by two reasons: a slight reduction in production, due to a Mines Regulation Act (1872), which reduced working hours for miners, and a strong increase in demand, induced by a prosperous iron industry following the American Civil War and the FrancoPrussian war. ${ }^{32}$ But more fundamentally, the report stated that

the coal trade (has) been no exception to the violent fluctuations which arise when the ordinary course of business is disturbed on account of unusually high prices, by panic demands for the moment, and speculation for the rise or fall. ${ }^{33}$

Therefore, the purpose of this Committee was, from the beginning, to "dissipate many popular delusions as to (...) the high price of coal" ${ }^{34}$ This was repeated over and over again in the press, and in Parliament, not least by those who had set up the Committee ${ }^{35}$, and who hoped that it would "remove a considerable amount of misapprehension which prevailed in the public mind on this subject". ${ }^{36}$ None of the MPs or Lords favouring the Committee seemed to think it would or should propose any solution: the natural laws of the market would, sooner or later, adjust the prices at a reasonable level. But the Committee could at least destroy the irrationality of the masses, and therefore not only appease the social climate, but also help reducing the prices, as it was the panic itself which was partly responsible for their increase.

\section{2) The panic continues}

14 In that matter, the Committee clearly failed. People were expecting results and action, not explanations. The indignation meetings continued well after the report, and especially in September 1873, when prices were still high and winter was coming closer. ${ }^{37}$ Some of the protesters deemed the report insufficient, and proposed to establish a new group, led by the Lord Mayor of London, to offer solutions. ${ }^{38}$ The agitation ceased only at the end of the year, when prices finally decreased "naturally".

One should of course distinguish between the panic of the population at large, deprived of coal, and who only asked for measures to reduce prices, and the anxiety of those who saw in this crisis the proof of Britain's unbearable allegiance to King Coal and the dangers of coal exhaustion. Both were expressed at the time, and the second was longer to calm down: it was discussed throughout the year 1873, and even later in 1874, in the general and more specialised press, in books and pamphlets, in papers given at learned societies 
and scientific associations. A telling example is the second edition of Warrington Wilkinson Smyth's Treatise on Coal, which was published after the report of the Royal Commission on coal supplies, and contained a second preface written in July 1872; in this text, the author at the same time supports the views of the Commission, and qualifies them, mentioning an "intricate problem" and the "more or less uncertainty" attached to such calculations ${ }^{39}$ Far more critical was a long article in the Contemporary Review written in 1874 by a radical industrialist, writer and journalist, William Rathbone Greg entitled "Rocks Ahead; or, The Warnings of Cassandra". Greg presented the 1873 famine as a warning of what would happen if coal became too expensive, and bluntly stated that "our coal is in process of exhaustion; it is daily and by a natural process becoming less abundant, and in consequence less cheap". ${ }^{40}$ The most commented upon of all the warnings was nonetheless the presidential address given by Sir William Armstrong to the North of England Institute of Mining and Mechanical Engineers in January 1873; he lamented the high prices of coal and their consequences for the poorest part of the population, and denounced the considerable waste of this fuel, both in production and consumption, that would accelerate the rate of exhaustion of British coal-fields. ${ }^{41}$

Magazines like Fun started to imagine a future where coal would be so dear that people would admire the exhibition of a "Coalinoor" or would stay in bed or gather in cooperatives to warm themselves together around a brazier. ${ }^{42}$ Others, like The Spectator denounced these alarming thoughts which made things worse: "little use is it to speculate over the probable speedy exhaustion of our coal-fields, for alarm spread upon that ground could only have the effect of making prices rise still more." ${ }^{43}$

Antoine Missemer has shown that Jevons and others saw indeed the 1873 coal famine as an example of what would happen in case of a gradual exhaustion of the mines. He has also analysed a debate that took place in 1878 at the Statistical Society, in which Jevons's book and warnings were accused to have contributed to the famine by triggering speculation on a rise of coal prices. ${ }^{44}$

Even though prices decreased indeed in 1874 , something changed afterwards: the average increase in coal prices in the following decades tended to be slightly higher than the general inflation, reversing the trend of previous years. ${ }^{45}$ The issue, moreover, came back more regularly in the following decades; it got a name from Jevons, "the Coal question", and reappeared each time prices were increasing in 1890 or 1900 for instance.

\section{An ideology of powerlessness}

It should be understood, nonetheless, why, in the end, nothing was really done to tackle the issue of coal shortage despite all those warnings. Even though coal was a dirty energy source, that created health problems and terrible and lethal smogs, ${ }^{46}$ there was no real policy that was implemented to offer substitutes. This was, I think, deeply grounded in what I would call an ideology of powerlessness inducing a policy of inaction. Such an ideology would comprise three main dimensions.

\section{1) An indomitable faith in progress}

The first dimension is the faith in progress and technique to solve all problems. After all, in the worst scenario - Jevons' - there would still be about a hundred years of coal 
available, and that would leave ample time for innovation. The wonders of the time electricity mainly, but also the telephone, cars, etc. - and all the changes brought by the $19^{\text {th }}$ century comforted this belief that solutions to the coal question would be found by scientists and inventors. Admittedly, this faith in progress became challenged in the last third of the century by 'back to nature' movements and the observation that the promises of abundance of the previous decades had not been met. ${ }^{47}$ Machines were indeed bringing some new evils and pollution, and steam engines perhaps more than others. But despite those criticisms, the global faith in technology as the best chance to solve Britain's problems remained unchallenged. This can be viewed for instance in the multiplication of utopias after the 1870s, most of which dealt with the issue of energy sources and coal. ${ }^{48}$ The great majority of them relied on technology to imagine the future, and only a few though often the best ones - could be seen as more critical and antimodernist. ${ }^{49}$ In such a frame of mind, there was no need either to worry or to act, as the laws of economics and the natural inventiveness of mankind would offer solutions in due time. This was, for instance, the position of Henry Hussey Vivian, a powerful Welsh industrialist and one of the members of the 1866 Royal Commission, who scoffed at the idea of an impending exhaustion of coal. ${ }^{50}$ In that sense, he perfectly embodied the beliefs of most industrialists at the time.

\section{2) The issue of export duties on coal}

These industrialists also agreed on a common defence of free trade. This is indeed the second dimension of the ideology of powerlessness: the deep-rooted faith in free trade and free enterprise, absolutely limiting any interference from the State. ${ }^{51}$ In the 1873 crisis, as mentioned earlier, no political solution was offered. In a letter to the Lord Provost of Glasgow, PM Gladstone confided: "The attention of Parliament is now fairly fixed on the question of the coal supply: \& this is all that I can say, for I do not see my way to specific remedies by the action of the Government". ${ }^{22}$ This was also the reason why Gladstone had refused, in the first place, any Parliamentary Committee on the dearness of coal in early February 1873, before surrendering to the pressure of his fellow MPs.

And yet, even though free trade became a national ideology, shared by most citizens of the UK, it never remained unchallenged, and fears of coal shortage like the one experienced between 1871 and 1873 reveal it clearly. Robert Peel had abolished taxes on coal export as early as 1845 , and they were reintroduced briefly in 1901 before being abolished again in 1906. Meanwhile, coal could be exported freely. It was also exported more and more massively: in 1830, only $1.6 \%$ of coal output (i.e. 0.5 million tons) was exported; this figure rose to $9.8 \%$ in 1869 (10.9 millions tons) and 26.8\% in 1913 (77 million tons). ${ }^{53}$ This is why many questioned the free-trade policy on the grounds of a growing fear of coal shortage. If coal was the staple of British economy, should it be allowed to flow out of the country without checks? Wasn't it too precious to be given so inexpensively to rival nations? This issue was raised at the beginning of the 1870s, from different places. Popular meetings, of course, voiced their indignation at seeing coal leave the country when it was so dear in Britain. On the $6^{\text {th }}$ of March 1873, an Irish Liberal MP asked during such a meeting for an export duty on coal, arguing that it was not contrary to his defence of free trade generally. Coal was exceptional, and should be treated as such. ${ }^{54} \mathrm{~A}$ few days before, someone reminded that Prime Minister Gladstone himself had defended such a tax in 1842, when he was Vice-President of the Board of Trade. ${ }^{55}$ Because 
of its numerous trade agreements with other European countries, it was difficult for Britain to impose such a tax, so it was suggested that Parliament should be petitioned to renegotiate these treaties. ${ }^{56}$ Many of the protesters were concerned with the isolated position of Britain, who was more and more standing alone in its absolute defence of free trade.

Reciprocity and limited trade-protection for coal thus became the motto of the day ${ }^{57}$ The chairman of a reciprocity society created in 1868 asked in 1873 to maintain free competition inside Britain, but to limit it outside, especially in the case of coal..$^{58}$ Even in the House of Commons some MPs started to question Gladstone and the government on the opportunity to maintain free trade for coal. ${ }^{59}$ All these demands were naturally dismissed by the authorities.

Some great names nonetheless joined their voice to this demand. Sir Alfred R. Wallace stands out among those. He fought for reciprocity and a duty on coal from this moment up to the end of the century. In a letter to the Daily News, he addressed the problem not only from an economic point of view, but also from a moral one:

I maintain that it is wrong to our own population, and a still greater wrong to the next generation, to permit the unlimited export of those mineral products which are absolute necessaries of life, but which, once destroyed, we can never reproduce. To do so is to sell and alienate for ever a portion of our land itself. ${ }^{60}$

Wallace's letter is another example of the acute sense of the limited supply of fossil fuels that ran accross Britain throughout the $19^{\text {th }}$ century. This growing challenge to free trade could also be understood as a shift of generation and ideology in the Liberal Party. Gladstonian Liberalism, based on financial orthodoxy and state abstention, was contested by a more interfering kind of liberalism: the election of Joseph Chamberlain as mayor of Birmingham in 1873 and the ensuing municipal gospel based on the supplying of cheap staple commodities like water and gas which could be seen as a powerful symbol of these new public expectations. ${ }^{61}$

\section{3) No help from abroad}

Hoping for a supply of coal from abroad, whether from other independent countries or from the British Empire, was no solution either. Indeed, what mattered was the upholding of cheap coal produced in Britain, so that the country could maintain its industrial and commercial supremacy over the world. The increase of the American output of coal, for instance, was a source of worry, not of relief, especially when it came to overcome the British one around $1900 .{ }^{62}$ Similarly, politicians and economists started to be concerned about coal exports to the British Empire. Yet, these may have been encouraged in the course of a "fossil imperialism" led by Britain to integrate its colonies to a worldwide economy that it dominated. ${ }^{63}$ On Barak has shown how this applied for instance in the case of the Ottoman Empire and Egypt: Britain encouraged the consumption of its coal, and used it as ballast in its steamboats for exports. ${ }^{64}$ of course, when the concerns about coal supply became acute, the situation was somewhat complicated. In India, for instance, the local production of coal was encouraged in the wake of the massive building of railways in the country following the Sepoy Mutiny in 1857-1858. But the Raj was still partly supplied by British coal, up to a third of its consumption according to Valentine Ball in $1881 .{ }^{65}$ Some hoped that the coal produced in the dominions for instance would 
compensate for a near exhaustion of the British fields, forgetting once again that this would in no way maintain the comparative advantage of cheap coal for Britain.

There was therefore no help to expect from abroad in the matter of coal dependence and in the quest for a way out. In that matter, Britain was alone - or, rather, far too integrated in the world economy it had created to expect any reprieve.

\section{4) A sense of doom}

The last justification for inaction was a sense of doom: yes, there would be a shortage of coal in the future, and the people of the time thus had a duty towards the next generations to at least reduce the National Debt, so that they would not have to cope with that too. This was Gladstone's, and most of the Liberals' position as early as 1866 . This fatalism can be explained by what an editorial of The Times, and an article in the Contemporary Review depicted as the paradox of coal, faced by British people ${ }^{66}$ : as their economy, and even their daily-life, depended on cheap coal, they desired low prices. But these low prices tended to encourage waste and, more generally, consumption. Therefore, the supply of coal was diminishing rapidly, quickening the moment when coal would become more expensive due to its scarcity, and thus hastening the decline of the country. In short, Britain needed high coal prices to preserve its coalfields and to extend the period of its supremacy; but the latter was based on low coal prices... Very few real solutions could be offered to get out of such an entanglement. There were only two which really made sense, and both aimed at preserving coal so that Britain would remain the greatest power as long as possible.

One of these solutions was to reduce the waste of coal both in its production and consumption. Sir William Armstrong, in the presidential address mentioned above, ${ }^{67}$ estimated that in steam engines and domestic consumption, half of the coal used was wasted. It is, however, difficult to assess whether the calls for savings in coal that ensued were heard and applied. Paul Warde has shown that the energy intensity of the British economy started to improve - ie to decrease - from the second half of the 1870s, so only a few years after these worries: they may have been heard after all ${ }^{68}$. Even if Armstrong's waste estimates were sometimes strongly contested ${ }^{69}$, his views were supported by influential people. In 1873, for instance, a Society for the Promotion of Scientific Industry was set up, and held its inaugural meeting in Manchester on the $16^{\text {th }}$ of January $1874 .{ }^{70}$ It organised this very year, with some success, an "exhibition of appliances for the economical consumption of fuel" in Peel Park, Salford. ${ }^{71}$ But here again, the solution to the coal question relied exclusively on technical innovations, and their acceptance by industrialists and citizens alike.

Another, more original and largely unheard, proposal was made by Sir Rowland Hill, the inventor of the penny post. A much admired man, he suggested at a meeting of the British Association for the Advancement of Science in December 1873, to maintain high prices of coal by implementing a coal tax, which would reduce waste; to make it bearable by the population and neutral to the standard of living, it would replace other taxes. ${ }^{72} \mathrm{He}$ was joined by John Ball, a geologist and member of the Alpine Club in a letter to The Times, who also defended relatively high prices of coal obtained by a tax on all coal raised. ${ }^{73}$ But I have found little trace of debate about their ideas. At the meeting of the BAAS, Rowland Hill's proposal was ridiculed, and it was hardly discussed in the press. ${ }^{74}$ It was nonetheless the only one to properly address the paradox of coal. 


\section{Conclusion}

31 scale of the changes required. In the course of the $19^{\text {th }}$ century, coal had become the cornerstone of a whole energetic system: British society was largely organised around the supply of coal. The economy depended on it: Britain would only remain the greatest power as long as its coal was cheaper and more abundant than in other countries. People's daily life was based on it: fireplaces were often the only source of heat and had the right size to burn coal. ${ }^{78}$ Hundreds of thousands of workers depended on it for their living, directly or not..$^{79}$ In a strongly polemical work, Timothy Mitchell has even argued that democratic progress was enhanced by the political and economic lever given to miners, whose strikes could put the whole country to a halt. ${ }^{80}$ There was even a whole cultural imagery associated with coal and smoke, mainly negative of course, but so deeply entrenched as to be part of a global vision of the world ${ }^{81}$ To change all this was of course a titanic enterprise and required a state intervention at a level inconceivable for most Victorian politicians.

34 The British Science Guild created in 1905 aimed at applying the methods of science to all social problems, and appointed a Conservation of Natural Sources of Energy Committee in 1909..$^{82}$ In the 1920s, a "coal research club" was set up, and published from 1922 onwards a journal entitled Fuel in science and practice. A journal of the scientific and economic use of fuels. 83

That the issue was nonetheless mainly political was asserted with increased vigour, when schemes of nationalisation multiplied with the support of the Labour Party and Trade Unions. The Miners' Federation of Great Britain passed a resolution on state ownership in 1894, but it was only with the First World War and the momentary state control of mines during the conflict that the measure grew in popularity and plausibility, at least among workers, until its completion in $1946 .{ }^{84}$

There are obvious parallels to be made with our current situation to fossil energies as a whole and oil in particular. In our case also, a whole system has to be upset to rid ourselves of our fuel addiction. But a main difference remains: in the case of Britain, the shortage was only national - there was still plenty of coal in the rest of the world - and its

Revue Française de Civilisation Britannique, XXIII-3 | 2018 
consequences would have been limited to a relative decline of the country, and certainly not reached the complete catastrophe usually painted. In that sense, the current global dimension of the issue of fossil fuels, and the environmental damages they create, are an utterly new challenge faced by our societies.

Charles-François Mathis is Senior Lecturer in Modern History at Bordeaux Montaigne University. His research focuses on the environmental and cultural history of the 19th century. He chairs the French network of environmental historians, and is editor of the "L'Environnement a une histoire" series (Champ Vallon edition). His publications include In Nature We Trust (2010), La Ville Végétale (with E-A. Pépy, 2017), and Qu'avons-nous fait du soleil? Mobilisation et dépense de l'énergie du Moyen Âge à nos jours (ed., with G. Massard Guilbaud, 2018).

\section{BIBLIOGRAPHY}

Ball, Valentine, The diamonds, coal and gold of India (London, Trübner, 1881).

Barak, On, « Politique asymétrique du carbone à l'ère du charbon ottoman, 1820-1911 », in Charles-François Mathis and Geneviève Massard-Guilbaud, Systèmes et transitions énergétiques. Les hommes et l'énergie du Moyen Âge à nos jours (Paris, Editions de la Sorbonne, forthcoming, 2019).

Briggs, Sir Asa, Victorian Things (Stroud, Sutton, 2003 ( $1^{\text {st }}$ ed.1988)).

Brown, Benjamin H., The Tariff Reform Movement in Great Britain, 1881-1895 (New York, Columbia University Press, 1943).

Cavert, William, The Smoke of London. Energy and Environment in the Early Modern City (Cambridge, CUP, 2016).

Church, Roy, The History of the British Coal Industry. 1830-1913: Victorian Pre-eminence (Oxford, Clarendon Press, 1986).

Claeys, Gregory, "Utopianism”, in Gregory Claeys (ed.), Encyclopedia of Nineteenth-Century Thought (London, Routledge, 2005).

Cook, Chris, The Routledge Companion to Britain in the $19^{\text {th }}$ century (London, Routledge, 2005).

Cullingford, Benita, Chimneys and Chimney Sweeps (Oxford, Shire Publications, 2003).

Delumeau, Jean, La Peur en Occident (Paris, Fayard, 1978).

Howe, Anthony, Free Trade and Liberal England, 1846-1946 (Oxford, Clarendon Press, 1997).

Hunt, Tristram, Building Jerusalem. The Rise and Fall of the Victorian City (London, Phoenix, 2005).

Jonsson, Fredrik Albritton, “Abundance and Scarcity in Geological Time 1784-1844" in Katrina Forester \& Sophie Smith (eds.), Nature, Action and the Future: Political Thought and the Environment (Cambridge, CUP, forthcoming)

Kander, Astrid, Malanima, Paolo \& Warde, Paul, Power to the People (Princeton, Princeton University Press, 2013). 
Kargon, Robert Hugh, Science in Victorian Manchester: Enterprise and Expertise (Manchester, MUP, 1977).

Lozé, Ed, Les Charbons Britanniques et leur Epuisement (Paris, Béranger, 1900).

Luckin, Bill, "Demographic, social and cultural parameters of environmental crisis: The great London smoke fogs", in Christoph Bernhardt \& Geneviève Massard-Guilbaud (eds.), Le Démon Moderne (Clermont-Ferrand, Presses Universitaires Blaise Pascal, 2002).

Maas, Harro, William Stanley Jevons and the Making of Modern Economics (Cambridge, CUP, 2005).

MacLeod, Roy, "Science for imperial efficiency and social change: reflections on the British Science Guild, 1905-1936”, Public Understanding of Science, 3:2, 1994, pp. 155-193.

Malm, Andreas, Fossil Capital. The Rise of Steam Power and the Roots of Global Warming (London/New York, Verso, 2016).

Marsh, Jan, Back to the Land (London, Quartet Books, 1982).

Mathis, Charles-François, « 'Renverser le Roi Charbon'. Imaginer la transition énergétique en Grande-Bretagne, 1865-1914”, in Yves Bouvier \& Léonard Laborie (eds.), L'Europe en transitions. Energie, mobilité, communication, XVIII ${ }^{e}-\mathrm{XXI}^{e}$ siècles (Paris, Nouveau Monde, 2016), pp. 85-118.

Missemer, Antoine, Les Economistes et la Fin des Energies Fossiles (1865-1931) (Paris, Classiques Garnier, 2017).

Mitchell, Timothy, Carbon Democracy (New York, Verso, 2011).

Mosley, Stephen, The Chimney of the World (Cambridge, White Horse Press, 2001).

Sieferle, Rolf Peter, The Subterranean Forest (Cambridge, The White Horse Press, 2001).

Simonin, Louis, La Vie Souterraine : les Mines et les Mineurs (Paris, Hachette, 1867).

Supple, Barry, The History of the British Coal Industry. 1914-1946: the Political Economy of Decline (Oxford, Clarendon Press, 1987).

Thorsheim, Peter, Inventing Pollution. Coal, Smoke and Culture in Britain since 1800 (Athens, Ohio University Press, 2006).

Trentmann, Frank, Free Trade Nation: Consumption, Civil Society and Commerce in Modern Britain (Oxford, OUP, 2008).

Verne, Jules, Les Indes Noires (Paris, Hetzel, 1877).

Warde, Paul, "Low carbon futures and high carbon pasts: policy challenges in historical perspective", History \& Policy, 1 December 2010.

Warde, Paul, Energy Consumption in England \& Wales, 1560-2004 (Naples, CNR, 2007).

Wrigley, E.A., Energy and the Industrial Revolution (Cambridge, CUP, 2010).

\section{NOTES}

1. John Williams, The Natural History of the Mineral Kingdom (Edinburgh, Ruddiman, 1789), pp. 172-173.

2. Paul Warde, Energy Consumption in England \& Wales, 1560-2004 (Naples, CNR, 2007).

3. E.A. Wrigley, Energy and the Industrial Revolution (Cambridge, CUP, 2010).

4. William Cavert, The Smoke of London. Energy and Environment in the Early Modern City (Cambridge, CUP, 2016). 
5. See Fredrik Albritton Jonsson "Abundance and Scarcity in Geological Time 1784-1844" in Katrina Forester and Sophie Smith (eds.), Nature, Action and the Future: Political Thought and the Environment (Cambridge, CUP, forthcoming). I also thank warmly Fredrik Albritton Jonsson for sharing some extracts of his on-going work on the issue of coal shortage on which the previous paragraph relies.

6. The Times, 31 October 1849 , p. 4.

7. See Rolf Peter Sieferle, The Subterranean Forest (Cambridge, The White Horse Press, 2001), chapter V and p. 189.

8. Jean Delumeau, La Peur en Occident (Paris, Fayard, 1978), pp. 38-39.

9. Stanley Jevons, The Coal Question (London, MacMillan, 1865).

10. There are many studies on Jevons's life and ideas. See for instance Harro Maas, William Stanley Jevons and the Making of Modern Economics (Cambridge, CUP, 2005). More recently, Antoine Missemer, in Les Economistes et la fin des Energies Fossiles (1865-1931) (Paris, Classiques Garnier, 2017), has brilliantly highlighted the originality of Jevons's theories in the context of these worries about coal exhaustion in Britain.

11. Stanley Jevons, The Coal Question, op. cit., chapters I and XI.

12. The Times: "Editorial", 13 June 1866, p. 8; "the coal question", 26 June 1866, p. 12; "Letter to the editor; coal”, 27 August 1866, p. 12.The Economist, 6 January 1866. The Saturday Review, 16 June 1866. Quarterly Review, “The coal question”, April 1866, pp. 435-472.

13. Colliery Guardian, 24 February 1866.

14. Colliery Guardian, all through the year.

15. Colliery Guardian, 26 May 1866, pp. 386-87.

16. "The coal panic", Colliery Guardian, 23 June 1866, pp. 464-465.

17. Sir Warrington Wilkinson Smyth, Treatise on Coal and Coal Mining (London, Lockwood \& co., 1873 ( $3^{\text {rd }}$ edition)), p. VII and p. 237.

18. Royal Commission appointed to inquire into the several matters relating to coal in the United Kingdom, General Report (London, HMSO, 1871), pp. XII-XIV.

19. Even though there was a form of rationality to the massive use of an abundant and powerful fuel like coal, such a shift away from more renewable sources of energy was not a necessity (see Andreas Malm, Fossil Capital (London, Verso, 2016) for instance): Britain became indeed addicted to coal in the sense that its dependence seemed to escape any form of control and was partly noxious (be it only on a sanitary level).

20. Roy Church, The History of the British Coal Industry. 1830-1913: Victorian Pre-eminence (Oxford, Clarendon Press, 1986), pp. 48-62. With an index of 100 in 1900, prices went from 50 in 1870, to 75,4 in 1872 , and 119,2 in 1873.

21. Select Committee on Dearness and Scarcity of Coal, Report (London, HMSO, 1873), p. IX.

22. Charles Mackay, "Old King Coal”, Illustrated London News, 1 January 1859, p. 12.

23. See for instance Leeds Mercury, 14 December 1866; The Preston Guardian, 5 April 1873; "Letters to the editor", The Times, 19 October 1872.

24. Fun, 1 March 1873.

25. The phrase is used in the article "The coal famine", The Freeman's Journal, $26^{\text {th }}$ February 1873 , p. 5, avowedly taken from a letter written to the Pall Mall Gazette.

26. "The High Price of Coal. Meeting in Nottingham Market-Place", The Nottinghamshire Guardian, 28 February 1873, p. 10.

27. “The High Price of Coal”, The Times, 1 April 1873, p. 7.

28. William Cavert, The Smoke of London, op. cit., chapter 7.

29. Bill Luckin has demonstrated that this was also the moment when more attention was given to atmospheric pollution, after the focus of previous years on water. See Bill Luckin, "Demographic, social and cultural parameters of environmental crisis: The great London smoke fogs", in Christoph Bernhardt and Geneviève Massard-Guilbaud (eds.), Le Démon Moderne 
(Clermont-Ferrand, Presses Universitaires Blaise Pascal, 2002), pp. 219-238. Peter Thorsheim, Inventing Pollution: Coal, Smoke, and Culture in Britain since 1800 (Athens, Ohio University Press, 2006), chapter 5 , also underlines the importance of the late $19^{\text {th }}$ century in the changing attitudes to pollution and coal.

30. PM Gladstone first refused the idea of such a committee on the $7^{\text {th }}$ of February 1873, to finally accept it under pressure from the House of Commons on the $21^{\text {st }}$.

31. Duke of Richmond, Hansard, House of Lords, 6 February 1873.

32. Select Committee on Dearness and Scarcity, Report (London, HMSO1873), pp. VII-XII.

33. Ibid., p. IX.

34. Leeds Mercury, 25 February 1873.

35. Mr Mundella, the MP who had proposed that the Committee be set up, or Mr Liddell, the MP who seconded the motion: Hansard, House of Commons, 21 February 1873

36. Mr Liddell, Hansard, House of Commons, 21 February 1873.

37. See for instance: The Sheffield Daily Telegraph, 24 September 1873, p. 3; "Dear Coal", The Times, 29 September 1873, p. 11; "Dear Coal", The Times, 7 October 1873, p. 7.

38. I have found no trace of such a committee in the archives I have consulted.

39. Sir Warrington Wilkinson Smyth, Treatise on Coal and Coal Mining, 1873 ( $3^{\text {rd }}$ edition), p. VI.

40. William Rathbone Greg, "Rocks Ahead; or, The Warnings of Cassandra. Part II", Contemporary Review, 24, June/November 1874, pp. 41-43.

41. Sir William Armstrong, "The Coal Supply", Presidential Address to the North of England Institute of Mining and Mechanical Engineers (Newcastle-upon-Tyne, A. Reid, 1873).

42. Fun, 1 March 1873, p. 92 and 26 December 1874, p. 14. "Coalinoor" is a pun about the "Koh-inoor", one of the biggest diamonds ever found, and one of the jewels of the crown.

43. The Spectator, 11 October 1873.

44. Antoine Missemer, Les Economistes et la Fin des Energies Fossiles (1865-1931), 2017, pp. 53-54.

45. Roy Church, The History of the British Coal Industry, p. 56.

46. See Peter Thorsheim, Inventing Pollution, op. cit., and Francis Albert Rollo Russell, London Fogs (London, Stanford, 1880).

47. Jan Marsh, Back to the Land (London, Quartet Books, 1982).

48. Charles-François Mathis, «'Renverser le Roi Charbon'. Imaginer la transition énergétique en Grande-Bretagne, 1865-1914 », in Yves Bouvier \& Léonard Laborie (eds.), L'Europe en Transitions. Energie, Mobilité, Communication, XVIII - XXI ${ }^{e}$ siècles (Paris, Nouveau Monde, 2016), pp. 85-118.

49. See Gregory Claeys, "Utopianism”, in Gregory Claeys (ed.), Encyclopedia of Nineteenth-Century Thought (London, Routledge, 2005), who distinguishes between dynamic and static (or frugal) utopias.

50. Henry Hussey Vivian, Hansard, House of Commons, 12 June 1866.

51. Frank Trentmann, Free Trade Nation: Consumption, Civil Society and Commerce in Modern Britain (Oxford, OUP, 2008).

52. William Ewart Gladstone to the Lord Provost of Glasgow, 22 February 1873, in Henry C. G. Matthew, The Gladstone Diaries, vol. VIII, July 1871-December 1874 (Oxford, Clarendon Press, 1982), p. 290.

53. Roy Church, The History of the British Coal Industry. 1830-1913: Victorian Pre-eminence (Oxford, Clarendon Press, 1986), table 1.3, p. 19.

54. The Nottinghamshire Guardian, 7 March 1873.

55. The Nottinghamshire Guardian, 28 February 1873, p. 2.

56. “The Committee on Coal", The Times, 1 April 1873, p. 7.

57. See for instance Benjamin H. Brown, The Tariff Reform Movement in Great Britain, 1881-1895 (New York, Columbia University Press, 1943), pp. 8-11; or Anthony Howe, Free Trade and Liberal England, 1846-1946 (Oxford, Clarendon Press, 1997), pp. 172-175. See also, for a contemporary comment: George Medley, The Reciprocity Craze (London, Cassell, 1881). 
58. “The High Price of Coal and Provisions”, The Times, 26 September 1873, p. 8.

59. See Hansard, House of Commons, 14 February 1873, col. 469-471.

60. Sir Alfred Wallace, "Free Trade Principles and the Coal Question", Daily News, 16 September 1873.

61. See for instance Tristram Hunt, Building Jerusalem. The Rise and Fall of the Victorian City (London, Phoenix, 2005), chapter 8.

62. Antoine Missemer, Les Economistes et la fin des énergies fossiles, op. cit., p. 50.

63. Andreas Malm is working on a sequel to his book Fossil Capital , provisionally entitled Fossil Empire.

64. On Barak, « Politique asymétrique du carbone à l'ère du charbon ottoman, 1820-1911 ", in Charles-François Mathis and Geneviève Massard-Guilbaud, Systèmes et Transitions Energétiques. Les Hommes et l'Energie du Moyen Âge à nos jours (Paris, Editions de la Sorbonne, forthcoming, 2019).

65. Valentine B all, The diamonds, coal and gold of India (London, Trübner, 1881), p. 94.

66. The Times, 4 mars 1873; William Rathbone Greg, "Rocks Ahead", art. cité. Sir Warrington Wilkinson Smyth, Treatise on Coal and Coal Mining, op. cit., p. 247 also describes a situation akin to such a paradox.

67. Sir William Armstrong, "The Coal Supply", op. cit., p. 8.

68. Paul Warde, "Low carbon futures and high carbon pasts: policy challenges in historical perspective", History \& Policy, 1 December 2010. Online: http://www.historyandpolicy.org/policypapers/papers/low-carbon-futures-and-high-carbon-pasts-policy-challenges-in-historical-pe.

For a presentation of the technical and economic reasons for this diminishing trend, see also Astrid Kander, Paolo Malanima \& Paul Warde, Power to the People (Princeton, Princeton University Press, 2013), pp. 232-247.

69. "The coal famine. Economies and remedies", The Engineer, 21 February 1873, p. 115.

70. Robert Hugh Kargon, Science in Victorian Manchester: Enterprise and Expertise (Manchester, MUP, 1977), p. 200.

71. The Manchester Courier and Lancashire General Advertiser, 20 April 1874, p. 6 mentions more than 50,000 visitors to the exhibition.

72. Sir Rowland Hill, "High Price of Coal. Suggestions for Neutralising its Evils", Journal of the Statistical Society of London, 36:4, 1873, pp. 565-579. The speech was actually read by Hill's son in law. See also Sir Asa Briggs, Victorian Things (Stroud, Sutton, 2003 ( $1^{\text {st }}$ ed.1988)), pp. 269-271.

73. Quoted in The Alnwick Mercury, 1 March 1873.

74. It is true that it ignored the fact that Britain's power depended on its comparative low coal prices on an international level.

75. Louis Simonin, La Vie Souterraine : lesMmines et les Mineurs (Paris, Hachette, 1867) ; Jules Verne, Les Indes Noires (Paris, Hetzel, 1877).

76. Ed Lozé, Les Charbons Britanniques et leur Epuisement (Paris, Béranger, 1900).

77. See Astrid Kander, Paolo Malanima and Paul Warde, Power to the People, op. cit., p. 274.

78. Benita Cullingford, Chimneys and Chimney Sweeps (Oxford, Shire Publications, 2003), p. 15-16.

79. 820,000 people were employed in coal mines in 1900 . Chris Cook, The Routledge Companion to Britain in the $19^{\text {th }}$ century (London, Routledge, 2005), p. 208.

80. Timothy Mitchell, Carbon Democracy (New York, Verso, 2011).

81. See for instance Stephen Mosley, The Chimney of the World (Cambridge, White Horse Press, 2001). Andreas Malm, Fossil Capital. The Rise of Steam Power and the Roots of Global Warming (London/ New York, Verso, 2016), chapter 9 also insists on the fascination for coal and its power in the Victorian society.

82. Roy MacLeod, "Science for imperial efficiency and social change: reflections on the British Science Guild, 1905-1936", Public Understanding of Science, 3/2, 1994, p. 166.

83. It appeared from 1922 to 1947. 
84. See for instance Barry Supple, The History of the British Coal Industry. 1914-1946: the Political Economy of Decline (Oxford, Clarendon Press, 1987).

\section{ABSTRACTS}

Fears of coal shortage emerged in Great Britain at the end of the 18th century, when coal became not only the basis of British people's daily lives, but also the staple of their economy. At the beginning of the 1870s, these fears intensified, following the publication of Stanley Jevons's book The Coal Question in 1865 and a very long and difficult coal famine. This made it more complicated to put aside the fears of shortage. That nothing was finally done to tackle this issue can be explained by a strong faith in science (to solve all problems) and in free trade (even though it began to be fiercely contested), but also by a sense of doom: getting out of a system entirely based on coal demanded efforts that seemed overwhelming compared to the immediate dangers of shortage or even pollution.

Les craintes d'une pénurie de charbon naissent en Grande-Bretagne à partir de la fin du XVIII siècle, lorsque cette énergie fossile devient le fondement non seulement du quotidien des Britanniques, mais aussi de leur économie. Au début des années 1870 , ces craintes s'intensifient à la suite de l'ouvrage The Coal Question de Stanley Jevons, mais aussi d'une famine de charbon particulièrement longue et difficile. La marginalisation de ces préoccupations devient ainsi plus compliquée. Mais elle s'opère finalement, grâce à la persistance d'une foi techniciste forte, du soutien au libre-échange (en dépit de résistances accentuées) et d'une forme de fatalisme liée aux efforts énormes qu'il faudrait pour sortir d'un système tout entier organisé autour du charbon.

INDEX

Mots-clés: Charbon, ère victorienne, Grande-Bretagne, écologie, énergies fossiles

Keywords: coal, Victorian era, Great Britain, energy, ecology, fossil fuels

\section{AUTHOR}

\section{CHARLES-FRANÇOIS MATHIS}

CEMMC, Université Bordeaux Montaigne 